\title{
Perlindungan Hukum bagi Tenaga Kerja Indonesia di Luar Negeri
}

\author{
Nina Rosida \\ Fakultas Hukum, Universitas Pancasila \\ Email: nina.rosida@gmail.com
}

\begin{abstract}
ABSTRAK
Kondisi negara yang pernah mengalami krisis ekonomi sekitar tahun 1997 menimbulkan dampak bagi ketenagakerjaan di Indonesia. Angka pengangguran yang semakin meningkat sehinggga upaya penanganan masalah ketenagakerjaan yang sangat penting. Hal tersebut menyebabkan banyaknya warga negara yang berbondong-bondong bekerja ke luar negeri. Penanganan tersebut harus diimbangi dengan kerjasama dengan yang solid dengan beberapa pihak, bukan hanya dari Pemerintah dan Pelaksana Penempatan Tenaga Kerja Indonesia Swasta tetapi juga ada kerja sama yang baik dengan calon Tenaga Kerja Indonesia tersebut agar tidak timbul permasalahan hukum yang terjadi antara Tenaga Kerja Indonesia yang bekerja di Luar Negeri dengan pihak majikan. Dengan demikian yang menjadi permasalahan adalah apa upaya pemerintah dalam memberikan perlindungan bagi Tenaga Kerja Indonesia di luar negeri menurut Undang-Undang Nomor 39 tahun 2004 tentang Penempatan dan Perlindungan Tenaga Kerja Indonesia di Luar Negeri dan apa upaya pemerintah untuk memberikan perlindungan bagi Tenaga Kerja Indonesia yang tidak berdokumen. Metode yang digunakan adalah metode normatif atau penelitian hukum kepustakaan, yaitu meneliti bahan pustaka atau data sekunder. Dari permasalahan dapat disimpulkan bahwa dalam hal memberikan perlindungan merupakan tanggung jawab Pemerintah dari pra penempatan, masa penempatan, dan purna penempatan. Prinsip-prinsip penempatan Tenaga Kerja Indonesia yang diatur dalam undang-undang yang harus di perhatikan, dan tidak menyalahi prinsip tersebut sehingga menjadikan kenyamanan bagi Tenaga Kerja Indonesia bekerja di Luar Negeri. Pelaksana penempatan TenagaKerja Indonesia hanya bisa dilakukan oleh Pemerintah melalui Badan Nasional Penempatan dan Perlindungan Tenaga Kerja Indonesia di Luar Negeri (BNP2TKI) dan Pelaksana Penempatan Tenaga Kerja Indonesia Swasta (PPTKIS) yang berbadan hukum. Selain itu dalam penempatan tenaga kerja indonesia harus membuat perjanjian kerjasama antara Pemerintah RI dengan Pemerintah negara tujuan dan penempatan Tenaga Kerja Indonesia (TKI) juga dilakukan pada negara tujuan yang mempunyai peraturan perundang-undangan yang melindungi Tenaga Kerja Asing. Diberlakukannya pengetatan peraturan dalam hal penempatan Tenaga Kerja Indonesia di luar negeri menyebabkan terjadi kenaikan prosentase penempatan TKI formal dan prosentase menurun pada penempatan TKI informal. Hal itu, karena pembenahan penempatan TKI di beberapa negara di kawasan timur tengah. Diberlakukannya penundaan penempatan (moratorium) TKI informal yang bekerja pada sektor Penata Laksana Rumah Tangga (PLRT) di 6 (enam) negara, yaitu; Kuwait, Yordania, Suriah, Arab Saudi, Qatar, dan uni Emerat Arab (UEA). Diberlakukannya moratorium TKI Penata Laksana Rumah Tangga (PLRT) di negara-negara tersebut dikarenakan negara itu tidak memberikan jaminan perlindungan.
\end{abstract}

Kata Kunci: tenaga kerja, perlindungan hukum, luar negeri, Indonesia

\section{PENDAHULUAN}

Berawal dari kondisi Negara yang mengalami krisis ekonomi yang terjadi pada sekitar tahun 1997 dan menimbulkan dampak yang sangat luas terhadap bangsa Indonesia. Salah satunya dari dampak tersebut adalah semakin tipisnya peluang kerja dalam negeri ini, sehingga meningkat pula jumlah pengangguran yang berujung pada ketidakberdayaan pemerintah untuk mengatasi kemiskinan seiring dengan tuntutan untuk memenuhi kebutuhan hidup masyarakat yang terus meningkat. Masalah ketenagakerjaan di Indonesia sekarang ini sudah mencapai kondisi yang cukup memprihatinkan ditandai dengan jumlah pengangguran yang tinggi.

Bekerja merupakan hak dasar yang dimiliki manusia untuk meningkatkan kualitas dan stabilitas kehidupannya, dengan bekerja manusia akan membentuk dirinya agar tetap eksis dalam mengatasi problematika hidupnya yang merupakan proses interaksi antar manusia. Oleh karena itu, negara menjamin hak tersebut yang diatur jelas dan tegas dalam Undang-Undang Dasar 1945, sebagaimana tercermin dalam Pasal 27 ayat (2) yang mengatakan bahwa "Warga Negara Indonesia berhak atas pekerjaan dan penghidupan yang layak bagi kemanusiaan". Artinya secara tidak langsung, negara dalam hal ini pemerintah menjamin setiap warga negara untuk 
memperoleh pekerjaan sesuai dengan minat dan kemampuannya. Akan tetapi kondisi sekarang yang kita dihadapi bahwa negara dalam hal ini adalah pemerintah belum mampu menyediakan lapangan kerja sebagaimana diamanatkan pada Pasal 27 ayat (2) Undang-Undang Dasar 1945. Melihat kondisi tersebut, maka pengiriman Tenaga Kerja Indonesia (TKI) ke luar negeri merupakan salah satu solusi nasional dalam rangka mengatasi kelangkaan kesempatan kerja, dan dianggap sebagai salah satu kebijakan pembangunan nasional dalam upaya menanggulangi pengangguran akibat terbatasnya ketersediaan lapangan kerja di dalam negeri. Selanjutnya dasar hukum tersebut dipertegas lagi dalam Pasal 28 D ayat (2) "Setiap orang berhak untuk bekerja serta mendapatkan imbalan dan perlakuan yang adil dan layak dalam hubungan kerja ". Sebagai pengejawantah dari amanat konstitusi sebagaimana diamaksud diatas, dalam Pasal 31 UndangUndang Nomor 13 Tahun 2003 tentang Ketenagakerjaan menyatakan bahwa " Setiap tenaga kerja mempunyai hak dan kesempatan yang sama untuk memilih, mendapatkan, atau pindah pekerjaan dan memperoleh penghasilan yang layak di dalam atau di luar negeri". Bahkan di dalam Pasal 38 ayat (2) Undang-Undang Nomor 39 Tahun 1999 tentang Hak Asasi Manusia menyatakan bahwa "Setiap orang berhak dengan bebas memilih pekerjaan yang disukainya dan berhak pula atas syarat-syarat ketenagakerjaan yang adil". Dengan demikian bekerja merupakan hak bagi setiap orang untuk meningkatkan kualitas hidupnya, dan mendapatkan pekerjaan menjadi sangat berarti karena pekerjaan menjadi sarana untuk memperoleh penghasilan guna memenuhi kehidupan baik untuk diri sendiri maupun keluarganya.

\section{Pokok Permasalahan}

1. Apa upaya pemerintah dalam memberikan perlindungan bagi Tenaga Kerja Indonesia (TKI) di luar negeri menurut Undang-Undang Nomor 39 tahun 2004 tentang Penempatan dan Perlindungan Tenaga Kerja Indonesia di Luar Negeri ?

2. Apa upaya pemerintah dalam memberikan perlindungan bagi Tenaga Kerja Indonesia (TKI) yang tidak berdokumen?

\section{METODE PENELITIAN}

Dalam melakukan suatu penulisan ilmiah diperlukan penelitian, oleh karena penelitian merupakan suatu sarana pengembangan ilmu pengetahuan dan teknologi. Hal ini disebabkan penelitian mempunyai tujuan, yaitu "untuk mengungkapkan kebenaran secara sistematis, metodelogi dan konsisten". Melalui proses penelitian tersebut dianalisa dan kontruksi terhadap data yang dikumpulkan dan diolah. Dalam penelitian ini, peneliti menggunakan penelitian normatif atau penelitian hukum kepustakaan, yaitu meneliti bahan pustaka atau data sekunder.

\section{HASIL DAN PEMBAHASAN}

Indonesia merupakan salah satu negara pengirim tenaga kerja ke luar negeri terbesar, diperkirakan sampai beberapa tahun yang akan datang. Sepanjang tahun 2016 Badan Nasional Penempatan dan Perlindungan Tenaga Kerja Indonesia (BNP2TKI) mencatat penempatan TKI ke berbagai negara di dunia sebanyak 234.451 orang. Jumlah itu meliputi 125.176 orang (53 persen) TKI formal dan 109.275 orang (47 persen) TKI informal.( BP2TKI, 2016) Banyaknya permasalahan yang timbul dalam bidang ketenagakerjaan khususnya TKI di luar negeri, salah satunya TKI ilegal yang bermasalah di negara tujuan.

Kenyataan empirik menjadi sebuah fakta yang tidak terbantahkan, bahwa fenomena TKI adalah gambaran dari kondisi buruknya tingkat hidup dan penghidupan masyarakat dari sudut pandang perekonomian. Dan selebihnya dikarenakan rendahnya tingkat pendidikan yang dimiliki, jumlah penduduk yang tinggi, sehingga terjadi ketidakseimbangan antara jumlah tenaga kerja (angkatan kerja) yang selalu bertambah dengan ketersediaan lapangan kerja. 
Penempatan TKI dalam jangka waktu empat tahun terakhir ini terjadi kenaikan prosentase penempatan TKI formal dan prosentase menurun pada penempatan TKI informal. Ada tiga penyebab (kemungkian) kenaikan jumlah prosentase penampatan TKI formal dan menurunnya prosentase penempatan TKI informal, yaitu (BNP2TKI, 2014):

Pertama, penurunan TKI informal karena pembenahan penempatan TKI di beberapa negara di kawasan timur tengah. Diberlakukannya penundaan penempatan (moratorium) TKI informal yang bekerja pada sektor Penata Laksana Rumah Tangga (PLRT) di 6 (enam) negara, yaitu; Kuwait, Yordania, Suriah, Arab Saudi, Qatar, dan uni Emerat Arab (UEA). Diberlakukannya moratorium TKI PLRT di negara-negara tersebut dikarenakan negara itu tidak memberikan jaminan perlindungan.

Kedua, diberlakukannya langkah pengetatan penempatan TKI dengan memberlakukan durasi waktu pelatihan yang dibuktikan melalui kehadiran sistem sidik jari (finger print).

Ketiga, ketersediaan tenaga kerja unskill di daerah benar-benar berkurang.

Tabel 1. Penempatan Tenaga Kerja Indonesia Tahun 2011 s.d 2017 (Januari)

\begin{tabular}{lllllll}
\hline No. & Tahun & Jumlah & TKI Formal & $\mathbf{\%}$ & TKI Informal & $\%$ \\
\hline 1. & 2011 & 586.802 & 266.191 & 45 & 320.611 & 55 \\
\hline 2. & 2012 & 494.609 & 258.411 & 52 & 236.198 & 48 \\
\hline 3. & 2013 & 512.168 & 285.297 & 56 & 226.871 & 44 \\
\hline 4. & 2014 & 429.872 & 247.610 & 58 & 182.262 & 42 \\
\hline 5. & 2015 & 275.736 & 152.394 & 55 & 123.342 & 45 \\
\hline 6. & 2016 & 234.451 & 125.176 & 53 & 109.275 & 47 \\
& 2016 (Januari) & 23.665 & 13.994 & 59 & 9.671 & 41 \\
\hline 7. & 2017 (Januari) & 14.845 & 7.779 & 52 & 7.066 & 48 \\
\hline \multicolumn{7}{r}{ Sumber data: Pusat Penelitian Pengembangan Dan Informasi (Puslitfo BNP2TKI) }
\end{tabular}

Sumber data: Pusat Penelitian Pengembangan Dan Informasi (Puslitfo BNP2TKI)

\section{Upaya Perlindungan bagi Tenaga Kerja Indonesia}

Pengerahan dan penempatan tenaga kerja merupakan titik berat upaya penanganan masalah ketenagakerjaan. Terlebih Indonesia tergolong negara yang memiliki jumlah penduduk peringkat atas di dunia, sehingga penempatan angkatan kerja juga harus diatur sedemikian rupa dan secara terpadu. Prinsip penempatan tenaga kerja bahwa setiap tenaga kerja mempunyai hak kesempatan yang sama untuk memilih, mendapatkan, atau pindah pekerjaan dan memperoleh penghasilan yang layak di dalam atau diluar negeri.

Pada Pasal 32 ayat (1) Undang-Undang Nomor 13 Tahun 2003 tentang Ketennagakerjaan menyatakan bahwa penempatan tenaga kerja Indonesia dilaksanakan berdasarkan asas-asas, sebagai berikut (Khakim, 2003):

1. Terbuka, adalah pemberian informasi kepada pencari kerja secara jelas, antara lain jenis pekerjaan, besarnya upah, dan jam kerja. Hal ini dimaksudkan untuk melindungi pekerja/buruh serta untuk menghindari terjadinya perselisihan setelah tenaga kerja ditempatkan.

2. Bebas, adalah pencari kerja bebas memilih jenis pekerjaan dan pemberi kerja bebas memilih tenaga kerja, sehingga tidak ada pemaksaan satu sama lain.

3. Objektif, adalah pemberi kerja agar menawarkan pekerjaan yang cocok kepada pencari kerja sesuai dengan kemampuan dan persyaratan jabatan yang dibutuhkan, serta harus memperhatikan kepentingan umum dengan tidak memihak kepentingan pihak tertentu. 
4. Adil dan setara tanpa diskriminasi, adalah penempatan tenaga kerja dilakukan berdasarkan atas ras, jenis kelamin, warnakulit, agama, dan aliran politik.

Sedangkan sasaran penempatan tenaga kerja diatur dalam Pasal 32 ayat (2) Undang-Undang Nomor 13 tahun 2003 yaitu " penempatan tenaga kerja diarahkan untuk menempatkan tenaga kerja pada jabatan yang tepat sesuai dengan keahlian, ketrampilan, bakat, minat dan kemampuan dengan memperhatikan harkat, martabat, hak asasi dan perlindungan hukum. Ruang lingkup pengerahan dan penempatan tenaga kerja tidak hanya penempatan tenaga kerja di dalam negeri tetapi juga penempatan tenaga kerja di luar negari. Penempatan tenaga kerja di luar diatur dengan menggunakan undang-undang tersendiri. Ketentuan Pasal 34 Undang-Undang Nomor 13 Tahun 2003 tentang Ketenagakerjaan mengamatkan bahwa ketentuan mengenai penempatan tenaga kerja di luar negeri diatur dengan undang-undang tersendiri, sehinggga terbitlah UndangUndang Nomor 39 Tahun 2004 tentang Pelaksanaan dan Penempatan Tenaga Kerja di Luar Negeri (PPTKILN).

Berdasarkan ketentuan Pasal 1 angka 3 Undang-Undang Nomor 39 Tahun 2004 tentang PPTKILN, istilah Antar Kerja Antar Negara (AKAN) disamakan dengan istilah Penempatan Tenaga Kerja Indonesia (TKI), yaitu kegiatan pelayanan untuk mempertemukan TKI sesuai dengan bakat, minat, dan kemampuannya dengan pemberi kerja di luar negeri yang meliputi keseluruhan proses pengkrekutan, pengurusan dokumen, pendidikan dan pelatihan, penampungan, persiapan pemberangkatan, pemberangkatan sampai ke negara tujuan, dan pemulangan dari negara tujuan.

Pada prinsipnya dalam hal penempatan Tenaga Kerja Indonesia di Luar Negeri sebagaimana diatur dalam Undang-Undang Nomor 39 Tahun 2004 haruslah berdasarkan hal-hal sebagai berikut:

a. Orang perorangan dilarang menempatkan warga negara Indonesia di luar negeri (Pasal 4).

b. Pemerintah bertanggung jawab untuk meningkatkan upaya perlindungan Tenaga Kerja di luar negeri(Pasal 6).

c. Penempatan Tenaga Kerja Indonesia di luar negeri dilakukan ke negara tujuan (Pasal 27):

- Yang telah membuat perjanjian tertulis dengan Pemerintah Republik Indonesia; atau

- Negara tujuan yang telah mempunyai peraturan perundang-undangan yang mengatur dan melindungi Tenaga Kerja asing.

d. Larangan menempatkan calon Tenaga Kerja Indonesia/ Tenaga Kerja Indonesia pada jabatan dan tempat pekerjaan yang bertentangan dengan nilai-nilai kemanusiaan dan norma kesusilaan serta peraturan perundang-undangan, baik di Indonesia maupun di negara tujuan atau di negara tujuan yang telah dinyatakan tertutup sebagaimana dimaksud dalam Pasal 27 ayat (2).

e. Setiap calon Tenaga Kerja Indonesia/ Tenaga Kerja Indonesia berhak memperoleh perlindungan sesuai dengan peraturan perundang-undangan mulai dari pra penempatan, masa penempatan, sampai dengan purna penempatan.

Dari uraian prinsip diatas, maka semakin jelas bahwa undang-undang telah memberikan aturan yang sangat jelas dan bertujuan untuk memberikan perlindungan bagi Tenaga Kerja Indonesia (TKI) di Luar Negeri. Namun, apabila kita melihat masih banyak segelintir orang atau Pelaksana Penempatan Tenaga Kerja Indonesia Swasta (PPTKIS) yang tidak melihat bahwa hal tersebut sangatlah penting guna memberikan perlindungan bagi Tenaga Kerja Indonesia tersebut. Menurut Pasal 10 Undang-Undang Nomor 39 Tahun 2004 tentang Pelaksana Penempatan 
Tenaga Kerja Indonesia di Luar Negeri, yang menjadi pelaksana penempatan Tenaga Kerja Indonesia (TKI) terdiri dari:

a. Pemerintah; melalui BNP2TKI

Pemerintah adalah perangkat Negara Kesatuan Indonesia yang terdiri dari Presiden beserta para Menteri. Penempatan TKI di Luar Negeri oleh Pemerintah hanya dapat dilakukan atas dasar perjanjian tertulis antara Pemerintah dengan Pemerintah Negara pengguna TKI atau Pengguna berbadan hukum di negara tujuan.

b. Pelaksana Penempatan TKI Swasta (PPTKIS).

Pelaksana Penempatan TKI Swasta adalah badan hukum yang telah memperoleh izin tertulis dari Pemerintah untuk menyelenggarakan pelayanan penempatan TKI di Luar Negeri. Pelaksana Penempatan TKI Swasta wajib mendapatkan izin tertulis berupa SIPPTKI (Surat Izin Pelaksana Penempatan TKI) dari Menteri (Pasal 12). Untuk mendapatkan SIPPTKI tidaklah mudah karena perusahaaan tersebut harus berbadan hukum yang didirikan berdasarkan peraturan perundang-undangan, memiliki modal di setor yang tercantum di dalam akta pendirian perusahaan sekurang-kurangnya sebesar Rp. 3.000.000.000,00 (tiga milyar rupiah), menyetor uang kepada bank sebagai jaminan dalam bentuk deposito sebesar Rp. 500.000.000,00 (lima ratus juta) pada bank pemerintah, memiliki rencana penempatan sekurang-kurangnya untuk 3 (tiga) tahun berjalan, memiliki unit pelatihan kerja, dan memiliki sarana dan preasarana pelayanan penempatan TKI.

Pelaksana Penempatan TKI di Luar Negeri sebagaimana di jelaskan diatas bisa dari Pemerintah melalui Badan Nasional Pelaksana Penempatan Tenaga Kerja Indonesia (BNP2TKI) maupun oleh Swasta atau biasa disebut PPTKIS. PPTKIS sebagai perusahaan yang bergerak dibidang jasa pelayanan penempatan TKI di luar negeri tentunya proses pelaksanaannya harus sesuai dengan prosedur yang telah ditentukan oleh pemerintah yang dalam hal ini adalah Kementerian Tenaga Kerja dan Transmigrasi bersama dengan BNP2TKI. Kebijakan yang memberikan perlindungan bagi TKI mulai dari pra penempatan, masa penempatan, dan purna penempatan. Perwakilan Republik Indonesia memberikan perlindungan terhadap TKI di luar negeri sesuai dengan peraturan perundang-undangan serta hukum dan kebiasaan internasional. Selain itu dalam rangka untuk memberikan perlindungan bagi TKI di luar negeri pemerintah dapat menempatkan jabatan Atase Ketenagakerjaan pada Perwakilan Republik Indonesia tertentu.

1. Pra Penempatan

a. Perekrutan dan seleksi

Employment order atau job order, adalah permintaan nyata dari pengguna jasa di negara calon tujuan pekerja migran untuk ditempatkan pada perusahan yang berbadan hukum atau penata laksana rumah tangga (domestic helper). Namun pada umumnya calon TKI datang kepada PPTKIS untuk dapat dikirim ke luar negeri. Apabila calon TKI tersebut datang melalui media promosi mungkin tidak masalah, namun sekarang ini banyak calon TKI datang kepada PPTKIS melalui sponsor atau calo. Sebenarnya pemerintah sudah melarang tindakan tersebut dan berdasarkan Undang-Undang Nomor 39 Tahun 2004 sudah diancam tindak pidana (Hamid, 2012).

Calon TKI yang akan mendaftar kepada PPTKIS wajib menyerahkan dokumen-dokumen sebagai berikut (PPTKILN UU No. 39 Tahun 2004, Pasal 51);

1. Kartu Tanda Penduduk, ijazah pendidikan terakhir, akte kelahiran, atau suarat keterangan kenal lahir;

2. Surat keterangan status perkawinan, bagi yang telah menikah melampirkan copy buku nikah;

3. Surat keterangan izin suami atau istri, izin orang tua, atau izin wali;

4. Sertifikat kompetensi kerja; 
5. Surat keterangan sehat berdasarkan hasil pemeriksaan kesehatan dan psikologi;

6. Paspor yang diterbitkan oleh kantor imigrasi setempat;

7. Visa kerja;

8. Perjanjian penempatan TKI;

Adalah perjanjian tertulis antara pelaksana penempatan TKI swasta dan calon TKI yang memuat hak dan kewajiban masing-masing pihak dalam rangka penempatan TKI di negara tujuan sesuai dengan peraturan perundang-undangan.

9. Perjanjian kerja; dan

Adalah perjanjian tertulis antara TKI dan pengguna yang memuat syarat-syarat kerja serta hak dan kewajiban masing-masing pihak.

10. Kartu Tanda Kerja Luar Negeri (KTKLN).

Dalam hal perekrutan calon TKI oleh pelaksana penempatan TKI swasta wajib dilakukan terhadap calon TKI yang telah memenuhi persyaratan, antara lain (PPTKILN UU No. 39 Tahun 2004, Pasal 35);

a. Berusia sekurang-kurangnya 18 (delapan belas )tahun kecuali bagi TKI yang akan dipekerjakan pada pengguan perorangan sekurang-kurangnya 21 (dua puluh satu) tahun;

b. Sehat jasmani dan rohani;

c. Tidak dalam keadaan hamil bagi calon TKI perempuan; dan

d. Berpendidikan sekurang-kurangnya lulus Sekolah Lanjutan Tingkat Pertama (SLTP) atau sederajat.

2. Masa Penempatan

Setelah sampai negara tujuan, TKI harus melapor kepada pihak imigrasi, kemudian mengambil barang-barang untuk di periksa di bagian pabean. Selain itu TKI akan diberikan pengarahan dari pihak Kementerian Tenaga Kerja dan Transmigrasi bersama BNP2TKI tentang tatacara bekerja di negara tujuan, hak dan kewajiban para calon TKI, tata cara beradaptasi dengan majikan dan arahan-arahan lain ketika bermasalah dengan majikan. Dalam kesempatan tersebut para calon TKI juga mendapatkan beberapa buku panduan untuk digunakan sebagai acuan (Hamid, 2012). Selain itu, dalam rangka memberikan perlindungan selama masa penempatan TKI di luar negeri, perwakilan Republik Indonesia melakukan pembinaan dan pengawasan terhadap perwakilan PPTKIS dan TKI yang ditempatkan di luar negeri. Dalam hal memberikan perlindungan selama masa penempatan TKI di luar negeri dilaksanakan antara lain (PPTKILN UU No. 39 Tahun 2004, Pasal 35);

a. Pemberian bantuan hukum sesuai dengan ketentuan perundang-undangan di negara tujuan serta hukum dan kebiasaan internasional;

b. Pembelaan atas pemenuhan hak-hak sesuai dengan perjanjian kerja dan/atau peraturan perundang-undangan di negara TKI ditempatkan.

3. Purna penempatan

Saat TKI akan kembali ke Indonesia wajib melaporkan kepulangannya kepada perwakilan Republik Indonesia negara tujuan. Kepulangan TKI dari negara tujuan sampai tiba di daerah asal merupakan tanggung jawab dari pelaksana penempatan TKI. Para TKI yang baru kembali dan yang telah didata diperbolehkan untuk pulang dengan dijemput oleh pihak sponsor dalam hal ini biasanya dilakukan oleh PPTKIS yang memberangkatkannya atau pulang sendiri ke daerah asal dengan menggunakan jasa angkutan/trevel yang di tunjuk oleh pemerintah (Hamid, 2012). 


\section{Perlindungan TKI yang tidak berdokumen}

Meskipun telah diupayakan adanya peningkatan dan perhatian dunia terhadap migrasi internasional dan buruh migran, tetapi belum terjadi dampak nyata terhadap hak-hak TKI yang tak berdokumen dan TKI PLRT, mengingat sampai sekarang masih tetap di luar sistem hukum efektif di negara manapun, secara nasional maupun internasional. Pendekatan penegakan hukum terhadap pengaturan migrasi di negara-negara tujuan menempatkan TKI tak berdokumen pada posisi yang paling tidak menguntungkan, karena mereka harus menanggung konsekuensi dijadikan sasaran perlakuan sinis, dianggap sebagai pelaku kriminal dan dilabeli "ilegal". Seiring dengan meningkatnya TKI yang bekerja di luar negeri, meningkat pula kasus perlakuan yang tidak manusiawi terhadap TKI. Kasus tersebut beragam dan bahkan berkembang kearah perdagangan manusia (trafficking) yang dapat dikatakan sebagai kejahatan terhadap kemanusiaan.

Pelanggaran hak-hak TKI oleh pengguna jasa TKI di negara tujuan merupakan masalah utama yang belum dapat di selesaikan oleh Pemerintah Indonesia. Salah satu pelanggaran yang sering dilakukan oleh pengguna jasa TKI antara lain penganiayaan, gaji tidak dibayarkan, tindakan asusila, sampai dengan perdagangan manusia (trafficking). Begitu kompleks permasalahanpermasalahan yang dihadapi Pemerintah Indonesia dalam mengatasi persoalan tersebut. Diperlukan langkah-langkah konkret untuk mengatasi tidak konsistennya kerangka perlindungan hukum di satu pihak dan tingginya permintaan pasar terhadap buruh migran tak berdokumen di pihak lain. Kemudian diperlukan bagi pemerintah negara-negara yang selama ini menjadi tujuan TKI ilegal seperti Malaysia, tidak tergesa-gesa melabeli TKI yang tidak berdokumen sebagai manusia kriminal dan seenaknya ditangkap, dicambuk, dipenjara, dan kemudian dipulangkan dengan cara tidak manusiawi (Rahman, 2011). Sebelum dilakukan tindakan tersebut hendaknya diliat secara lengkap, adakah kemungkinan bagi TKI tersebut menjadi korban penipuan dari pelantara penempatan TKI, padahal TKI tersebut telah menyerahkan sejumlah uang agar diurus segala dokumen sebagai kelengkapan untuk menjadi TKI di luar negeri. Mengingat tak jarang terjadi kasus demikian.

Keberadaan TKI di luar negeri, sudah diupayakan untuk mendapat perlindungan dari berbagai pihak yang terkait, terutama dari Pemerintah, terbukti dengan ditingkatkannya pemberian informasi kepada masyarakat, serta telah dikeluarkannya instrumen peraturan perundangundangan yang secara langsung dan tidak langsung telah menekan terjadinya kasus pelanggaran HAM terhadap para TKI. Upaya untuk meningkatkan perlindungan terhadap TKI ada beberapa hal yang selama ini telah dilakukan oleh pemerintah, diantaranya adalah (Rahman, 2011):

1. Perlindungan dengan pendekatan secara politis

Pendekatan politis dilakukan secara konkret yang dilakukan oleh Pemerintah untuk mengupayakan perlindungan TKI di luar negeri dengan membuat perjanjian kerjasama antar Pemerintah atau $\mathrm{G}$ to $\mathrm{G}$ (Goverment to Goverment) dari negara pemerima maupun negara pengirim TKI, kerjasama G to NGO (Goverment to Non Goverment Organization), kerjasama dengan organisasi keagamaan, dan kerjasama $\mathrm{G}$ to privat atau privat to privat. Kerjasama G to G (Goverment to Goverment) dari negara penerima TKI, dilakukan dengan bentuk Momerandum of Undertanding (MoU), arrangement atau perjanjian bilateral. Hal demikian diupayakan karena apabila hubungan kerjasama G to G (Goverment to Goverment) dengan negara penerima tidak dilandasi dengan MoU, maka terbatas pada konvensi Wina 1963 yang mengharuskan setiap perwakilan negara asing tetap menghormati kedaulatan dari otoritas negara tuan rumah. Hal ini dipastikan dapat menghambat pelaksanaan perlindungan TKI yang dilakukan pemerintah RI di Negara penerima TKI yang bersangkutan. 
2. Pembentukan Badan Nasional Penempatan dan Perlindungan Tenaga Kerja Indonesia (BNP2TKI)

Untuk mengoptimalkan perlindungan TKI di luar negeri yang lebih terpadu, pemerintah membentuk suatu badan bersifat nasional yang bertugas untuk melindungi TKI di luar negeri. Sebuah lembaga pemerintah Non Departemen yang bertanggung jawab kepada Presiden yang berkedudukan di ibu kota Negara yaitu Badan Nasional Penempatan dan Perlindungan Tenaga Kerja Indonesia (BNP2TKI), yang berfungsi melaksanakan kebijakan penempatan dan perlindungan TKI di luar negeri secara terkoordinir dan terintegrasi, dengan beberapa tugas sebagai berikut (PPTKILN UU No. 39 Tahun 2004, Pasal 95 ayat 2):

1. Melakukan penempatan atas dasar perjanjian secara tertulis antara pemerintah dengan pemerintah negara pengguna TKI atau pengguna berbadan hukum di negara tujuan.

2. Memberikan pelayanan, mengkoordinasikan, dan melakukan pengawasan mengenai: dokumen, pembekalan akhir pemberangkatan (PAP), penyelesaian masalah, sumbersumber pembiayaan, pemberangkatan sampai pemulangan, peningkatan kualitas calon TKI, informasi, kualitas pelaksana penempatan TKI, dan peningkatan kesejahteraan TKI dan keluarganya.

3. Pemberian Bantuan Kemanusiaan

Perlindungan dalam bentuk bantuan kemanusiaan ini diberikan kepada TKI yang sedang menjalani proses peradilan di negara setempat, dikarenakan adanya tuduhan telah melakukan tindak pidana. Perlindungan yang semacam ini biasanya dilakukan dengan bentukkunjungan secara priodik dan pemantauan serta memberikan dorongan moril kepada TKI yang mengalami masalah. Bantuan lainnya adalah pemenuhan kebutuhan pokok seharihari selama dalam proses menjalani peradilan, menyediakan rohamiwan dan memberikan layanan kesehatan/psiko sosial, serta mambantu pemulangan TKI ke tanah air. Misalnya membuat kebijakan akan memulangkan orang pendatang termasuk juga TKI yang tidak berdokumen, maka pemerintah mengalokasikan anggaran untuk memberikan layanan kepada TKI bermasalah, terutama TKI yang memanfaatkan masa amnesti untuk pulang ke Indonesia. Mengingat bahwa sebagian besar TKI amnesti mampu membiayai pemulangan mereka dan keluarganya sampai ke daerah asal masing-masing, maka penggunaan dana tersebut hanya untuk hal-hal yang sangar emergency yang berkaitan dengan masalah kemanusiaan.

4. Pemberian Bantuan Hukum

Selama ini bantuan hukum yang diberikan kepada TKI adalah:

a. Pemdampingan;

b. Konsultasi mengenai hukum yang berlaku di negara setempat;

c. Bertindak sebagai moderator dalam menyeleaikan perselisihan antara TKI dan pengusaha;

d. Menyediakan advokad baik yangbersifat pro bono maupun free paying.

Dalam bentuk bantuan hukum seperti itu, pemerintah Indonesia pernah meminta jasa 10 pengacara di Malaysia untuk menggugat secara hukum para pengusaha yang tidak membayar gaji TKI.

\section{KESIMPULAN DAN SARAN \\ Kesimpulan}

1. Upaya perlindungan Tenaga Kerja Indonesia (TKI) yang bekerja di luar negeri mulai dari pra penempatan, masa penempatan, dan purna penempatan. Dalam masa pra penempatan calon TKI harus menyerahkan dokumen-dokumen dan persyaratan yang harus diserahkan kepada PPTKIS. Dalam hal memberikan perlindungan selama masa penempatan TKI di luar negeri dilaksanakan dengan bantuan hukum sesuai dengan ketentuan perundang-undangan di 
negara tujuan serta hukum dan kebiasaan internasional dan atas pemenuhan hak-hak sesuai dengan perjanjian kerja dan/atau peraturan perundang-undangan di negara TKI ditempatkan. Sedangkan, pada masa purna penempat para TKI yang baru kembali dan yang telah didata diperbolehkan untuk pulang dengan dijemput oleh pihak sponsor dalam hal ini biasanya dilakukan oleh PPTKIS yang memberangkatkannya atau pulang sendiri ke daerah asal dengan menggunakan jasa angkutan/trevel yang di tunjuk oleh pemerintah.

2. Perlindungan bagi TKI tidak berdokumen dapat dilakukan pertama, dengan cara Perlindungan dengan pendekatan secara politis. Pendekatan politis dilakukan secara konkret yang dilakukan oleh Pemerintah untuk mengupayakan perlindungan TKI di luar negeri dengan membuat perjanjian kerjasama antar Pemerintah atau $\mathrm{G}$ to $\mathrm{G}$ (Goverment to Goverment) dari negara pemerima maupun negara pengirim TKI, kerja sama G to NGO (Goverment to Non Goverment Organization), kerjasama dengan organisasi keagamaan, dan kerjasama G to privat atau privat to privat. Kerjasama G to G (Goverment to Goverment) dari negara penerima TKI, dilakukan dengan bentuk Momerandum of Undertanding (MoU), arrangement atau perjanjian bilateral. Kedua, Pembentukan Badan Nasional Penempatan dan Perlindungan Tenaga Kerja Indonesia (BNP2TKI), yang tugasnya melakukan penempatan atas dasar perjanjian secara tertulis antara pemerintah dengan pemerintah negara pengguna TKI atau pengguna berbadan hukum di negara tujuan dan memberikan pelayanan, mengkoordinasikan, dan melakukan pengawasan mengenai: dokumen, pembekalan akhir pemberangkatan (PAP), penyelesaian masalah, sumber-sumber pembiayaan, pemberangkatan sampai pemulangan, peningkatan kualitas calon TKI, informasi, kualitas pelaksana penempatan TKI, dan peningkatan kesejahteraan TKI dan keluarganya. Ketiga, Pemberian Bantuan Kemanusiaan kepada TKI yang sedang menjalani proses peradilan di negara setempat, dikarenakan adanya tuduhan telah melakukan tindak pidana. Keempat, pemberian bantuan hukum.

\section{Saran}

Pada dasarnya aturan di dalam Undang-Undang Nomor 39 Tahun 2004 tentang Penempatan dan Perlindungan Tenaga Kerja Indonesia di Luar Negei (PPTKILN) sudah memberikan perlindungan, namun undang-undang tersebut tidak bisa menjangkau sampai luar batas wilayah Negara sehingga diperlukan Perjanjian antar Pemerintah ( $G$ to $G$ ) karena negara yang menjadi tujuan pengiriman TKI belum tentu memiliki peraturan perundang-undangan yang melindungi tenaga kerja asing. Selain itu, perlunya aturan tertulis mengenai buruh ilegal dan penanganannya yang dibentuk dalam peraturan perundang-undangan.

\section{REFERENSI}

BNP2TKI (2014). Sepanjang 2014 BNP2TKI mencatat Penempatan TKI 429.872 Orang. Diunduh dari http://www. bnp2tki.go.id //situs resmi Badan Nasional Penempatan dan Perlindungan Tenaga Kerja Indonesia, 16 Januari 2015.

BP2TKI (2016). Data Penempatan dan Perlindungan TKI periode 1 Januari s.d 31 Januari 2017. Diunduh dari http://www.bnp2tki.go.id//situs resmi Badan Nasional Penempatan dan Perlindungan Tenaga Kerja Indonesia, 9 Februari 2017.

Hamid, A. (2012). Menuju Kebijakan Yang Adil Bagi Buruh Migran. Jakarta: FHUP Press. Husni, L. (2012). Pengantar hukum ketenagakerjaan Indonesia edisi revisi. Jakarta: Raja Grafindo Persada.

Indonesia, Undang-Undang Dasar 1945.

Indonesia, Undang-Undang Republik Indonesia tentang Ketenagakerjaan, UU No. 13 Tahun 2003. 
Indonesia, Undang-Undang Republik Indonesia Tentang Pelaksana Penempatan Tenaga Kerja Indonesia di Luar Negeri (PPTKILN), UU No. 39 Tahun 2004.

Indonesia, Undang-Undang Nomor 39 Tahun 1999 tentang Hak Asasi Manusia

Khakim, A. (2003). Pengantar hukum ketenagakerjaan Indonesia berdasarkan Undang-Undang Nomor 13 Tahun 2003. Bandung: Citra Aditya Bakti.

Rahman, F. (2011). Menghakimi TKI mengurai benang kusut perlindungan TKI, Pensil-324. Jakarta. 